\title{
TRANSPLANTATION OF HUGE TREES FOR CONSTRUCTION OF PIERS OF MAGENTA METRO LINE AND OFFICE-CUM- INTERPRETATION CENTRE IN BOTANIC GARDEN OF INDIAN REPUBLIC, NOIDA
}

\section{Sheo Kumar}

Botanic Garden of Indian Republic, Botanical Survey of India Ministry of Environment, Forest and Climate Change

Government of India, NOIDA (U.P.), India

*Corresponding author: drsheo_kumar@rediffmail.com

Article Info:

Research Article Received

23.11.2021

Reviewed

31.12.2021

Accepted

30.01.2022

\begin{abstract}
To construct 9 piers of elevated track of magenta metro line to provide easy access to the commuters of South West Delhi including National and International tourists and a Porta-Cabin to use as an Office-cum-Interpretation Centre for exhibiting exhibits and organising awareness programme in Botanic Garden of Indian Republic (BGIR), the proposals were approved by the Competent Authority in Sep., 2014 and Nov., 2016 respectively. However, within the range, altogether 1,142 individuals of 31 species were found conserved and listed to rescue them from any damage or felling. After receipt of necessary permissions, manpower, general machineries (JCB and Hydra Crane) and other logistics, all plant individuals, comprising 1,075 individuals of 15 species of $<10 \mathrm{~cm}$ girth were transplanted manually and 167 individuals of 16 species of $>10 \mathrm{~cm}$ girth were transplanted mechanically without using specialized 'tree spade'. All transplanted plants were taken care of properly for a fortnight to months until and unless new leaves/branches/flower buds did not appear. Though environmental condition was not favourable, even then transplanted plants were survived@97.5\%, is one of the greatest achievements achieved so far. Even after 5 to 7 years from date of transplantation, all trees are still standing in their new locations in BGIR.
\end{abstract}

Keywords: Magenta metro line, Office-cum-Interpretation Centre, Transplantation, 97.5\% survival.

Cite this article as: Kumar Sheo (2022). Transplantation of huge trees for construction of piers of magenta metro line and Office-cum-Interpretation Centre in Botanic Garden of Indian Republic, NOIDA. International Journal of Biological Innovations. 4(1): 29-42. https://doi.org/10.46505/IJBI.2022.4103.

\section{INTRODUCTION}

The sapling of woody plants after plantation attain age and become tree with biomass, turn into breeding place and shelter house to other creatures and wildlife, alleviate adverse environmental conditions (ambient air, water and noise pollution), prevent soil erosion, recharge ground water, enhance aesthetic beauty, house property, health, socio-economic condition and reduce mental stress in many ways. No one may forget its importance in our daily life as it provides us without charging any 
per diem/weekly/monthly and/or annual fee for getting fibre, fodder, food, fuel, medicines, oxygen, timber, etc. from them as is being paid in shops, restaurants, hospitals and other commercial establishments. Hence, it is our duty to keep them alive wherever they develop by their own (and having some economic importance) and/or under various plantation and in-situ or exsitu conservation programme.

The development in rural and urban regions (including wetland and forested areas) is required to meet out the present and future need of population by producing different commodities using natural resources and their distribution through wide connecting road networks and fast transportation systems is invariably related with the boom of real estate, business, medical and educational institutions, etc. including infrastructural projects. However, these come at the cost of thousands of full grown/conserved trees, which face the axe on an exponential basis to give way for various expansive development projects. Before doing so, it needs to be realised that a fully matured tree once gone is gone forever. As per varying norms of different states and/or Central Government, planting saplings under 'compensatory plantation' may not fulfil instantly the vacuum of the benefits as the felled trees were providing for years (Das, 1979). Hence, it is imperative to protect full grown trees from felling whenever and wherever any one is going to propose and/or implement a proposal for any infrastructural, industrial or other developmental projects. Such thing should come out as part of their moral duty and efforts should be made to protect them from felling as much as possible for future generation and/or plan to opt for any feasible alternate option.

In this direction, during pre and post Independence periods in India and in State of Uttar Pradesh, several Acts have been enforced like the Indian Forest Act, 1927, Uttar Pradesh Protection of Trees in Rural and Hill Areas Act, 1976, Forest (Conservation) Act, 1980, National Forest Policy, 1988, Forest Act (Amended), 1992 and Uttar Pradesh Protection of Trees (Amendment) Act, 2001 need to be followed for protection from felling/damage of trees possibly because of any infrastructural and urban development, commercial activities, mining, farming, etc. By adopting any alternate method i.e. transplantation and/or relocation of projects may entail preservation of such targeted trees from felling for longer period to keep the ground cover as green and subsequent benefits likely provided by them for the welfare of living beings without charging any fee. Several alternate devices and methodologies have been suggested for the conservation of huge plants of different kinds as described by ANSI (2012), BSI (1989, 2010), Development Bureau (2014), Himelick (1981) and Watson (1996). Plantation imparts rich biodiversity, needed for ecological balance and sustainable development (Ashok, 2017; Verma, 2018, 2021; Kumar, 2021a, 2021b).

Other than relocation of proposed projects and/or felling the targeted full grown trees, transplantation of them with the help of mechanised support and massive machinery is very simple and most convenient way if it is being carried out by a 'tree spade' (a specialised mechanised machine for transplantation) which is readily not available in India. Under the circumstance, undertaking such work becomes very herculean for transplanting huge/full grown trees using other general machineries (i.e. JCB and Hydra Crane). The details of method and process adopted for successful transplantation of huge trees was made possible and described in detail in present communication as it was undertaken 2 times in Botanic Garden of Indian Republic (BGIR), NOIDA by keeping one thing in mind with holistic approach, firm determination/ commitment, scientific planning and adopting safety measure to minimise/avoid any kind of lapse and/or chances of failure and loss of marked/listed tree from felling. Thus, this kind of know-how or transplantation process may be taken as ready reference while going for any future infrastructural or other developmental projects by the developers.

\section{MATERIALS AND METHODS}

NOIDA (New Okhla Industrial Development Authority) is a planned and multifaceted city located in Gautam Buddh Nagar of Uttar Pradesh, as being part of Delhi NCR playing important role in nation's development. Most part of the land 

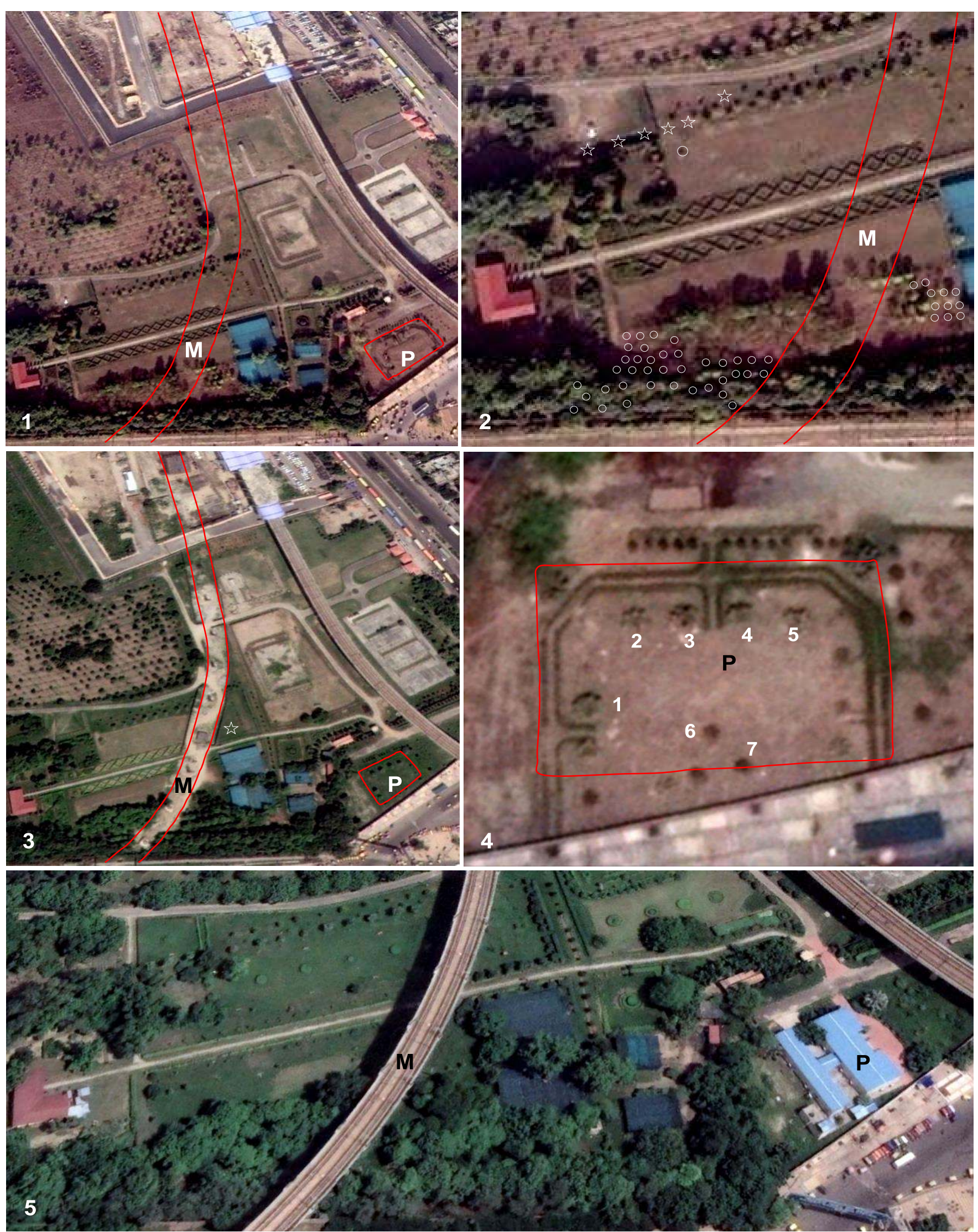

Photo Plate I: 1. Proposed magenta metro lines originating from Botanic Garden Metro Station (M) and construction site of Porta-Cabin for Office-Cum-Interpretation Centre (P), 2. Location of trees/plants transplanted (circle is showing location of transplanted trees from alignment of metro line and star is of transplanted trees from proposed area of Porta-Cabin), 3. Foundation of 9 piers developed within the alignment for metro route, 4 . Root balls of 7 trees at site of Porta-Cabin were made for transplantation, 5. Evident luxuriant growth of transplanted trees even after 5 to 7 years and developed metro line (M) and Porta-Cabin (P). 


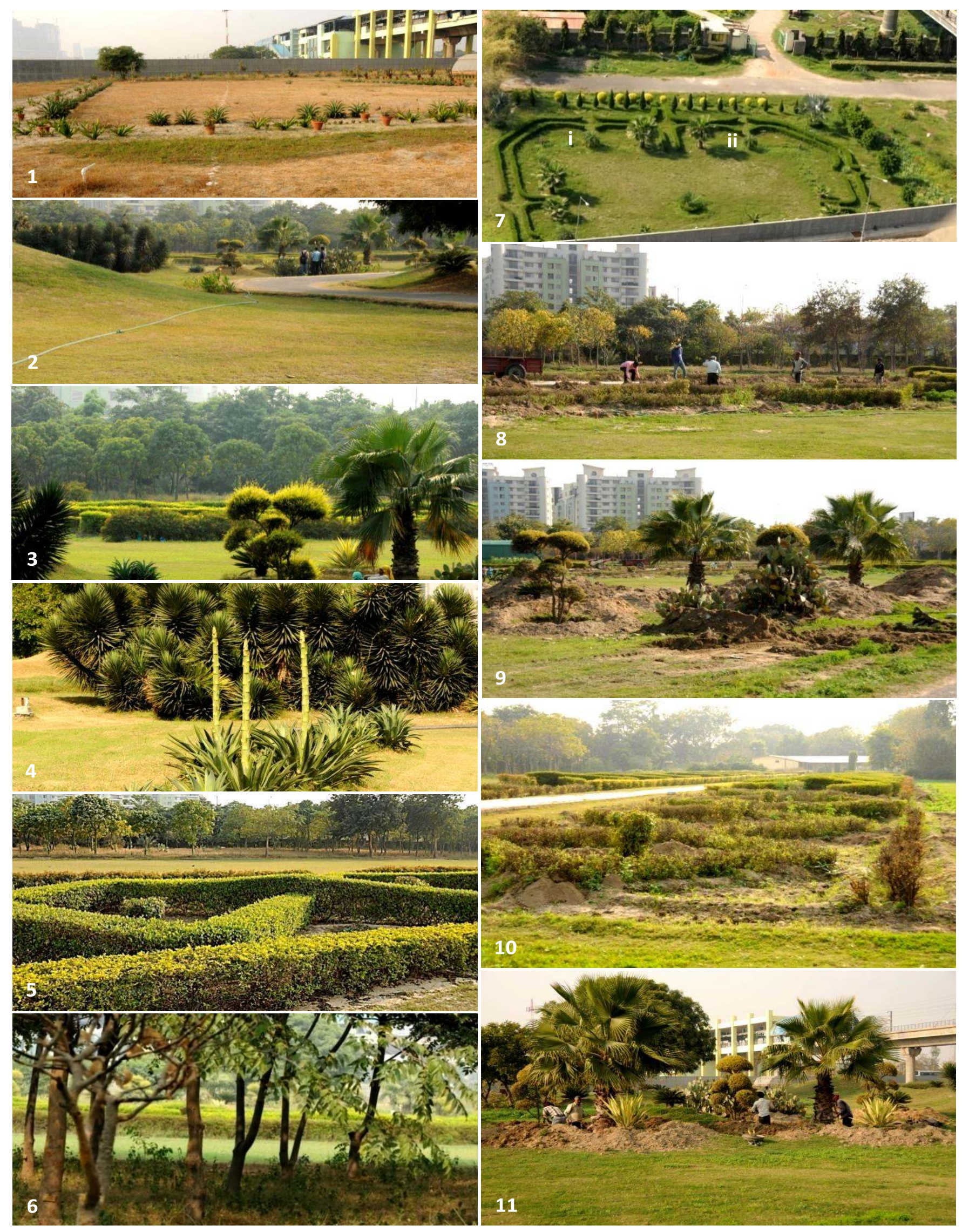

Photo Plate II: 1 . Construction site of additional Metro Station for Magenta Lines behind the boundary wall and piers inside Botanic Garden, 2. to 6. Different plant species falling under alignment for transplantation due to development of above new metro route by NOIDA, 7. Construction site of a Porta-Cabin for Interpretation Centre (i and ii were replaced by transplantation of Washingtonia robusta H.Wendl. in 2015 found within the alignment of metro route), 8. to 11. Process of transplantation is in progress manually and mechanically. 


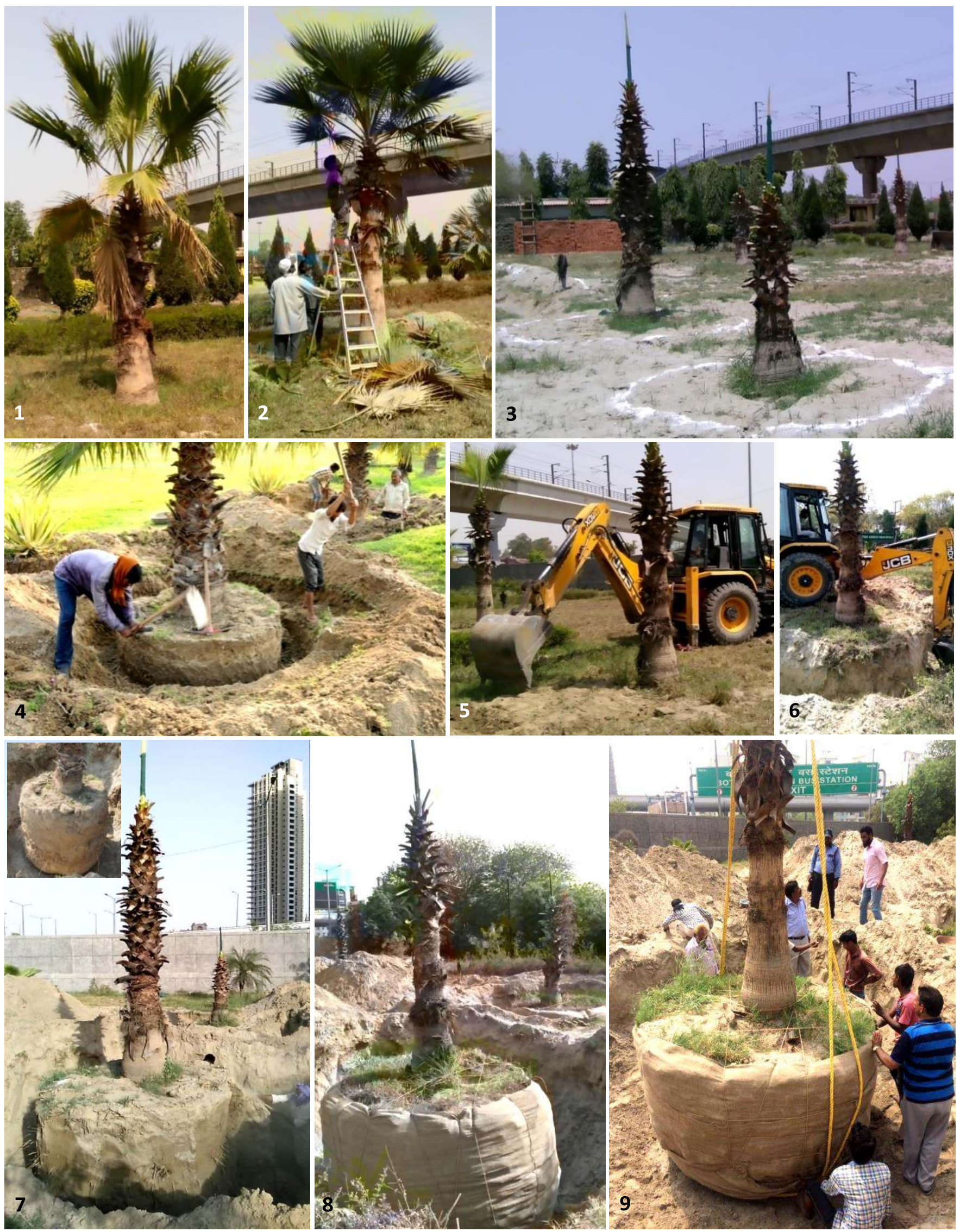

Photo Plate III: 1. Marking of a tree i.e. Washingtonia robusta H.Wendl. to be transplanted, 2. Removing mature leaves, 3. After binding young leaves together, area around tree is marked for digging outside the line, 4 . to 6 . Digging is in progress manually and mechanically by JCB, 7. Mechanically made root ball (In inset, manually made root ball), 8. Root ball packed in jute sheet/cloth using jute rope, 9. Tree is ready to be lifted mechanically by a crane. 


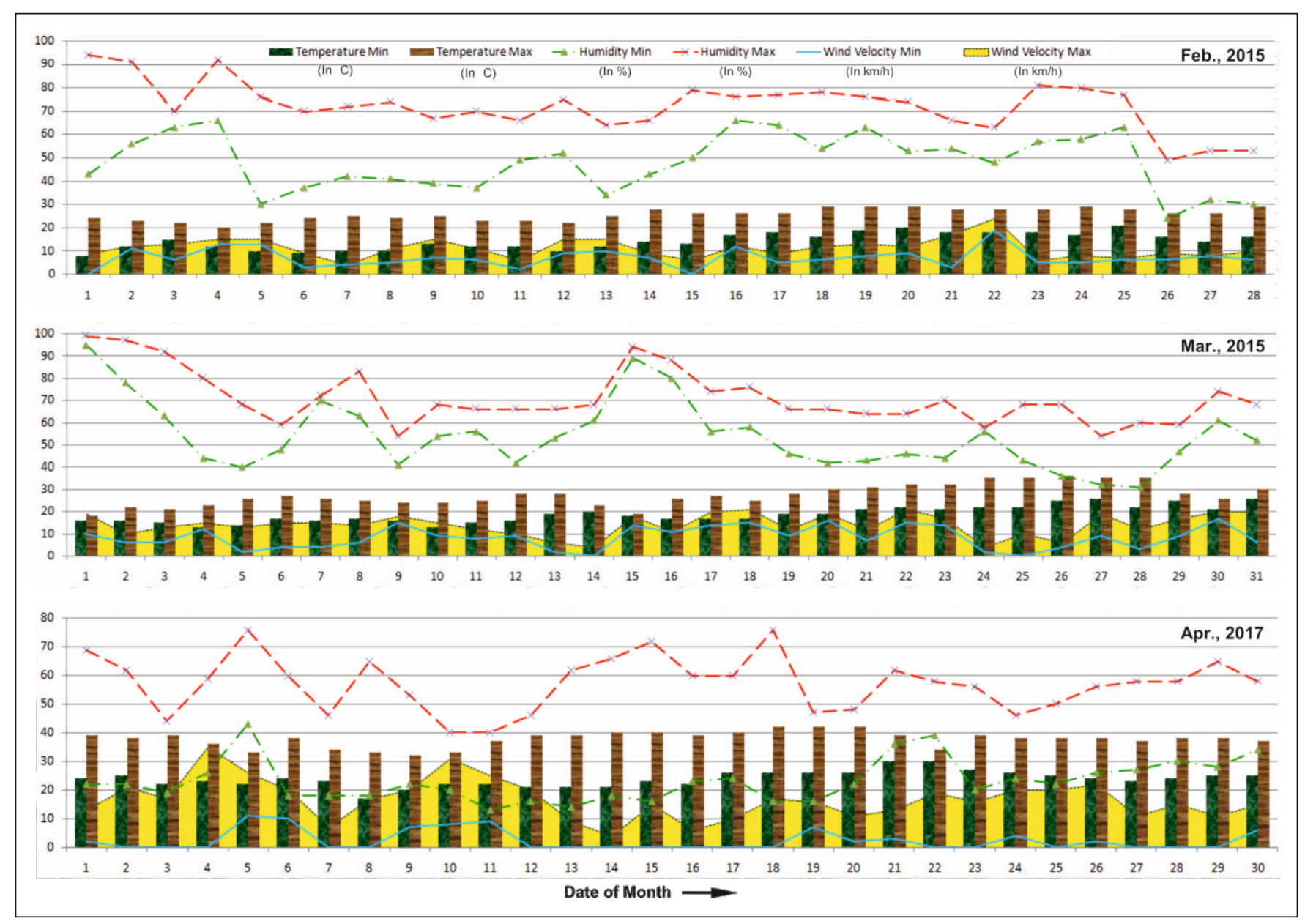

Fig. 1: Variation in meteorological characteristics recorded during months (i.e. Feb. and Mar., 2015 and Apr., 2017) of transplantation in Botanic Garden of Indian Republic, NOIDA.

area of NOIDA is on sand bed of river Yamuna over which Botanic Garden of Indian Republic (BGIR) is also established by the Government of India to meet the requirements of the Convention on Biological Diversity (CBD). To provide easy access to the huge number of commuters of South West Delhi including National and International tourists from Indira Gandhi International Airport in NOIDA and vice versa, a new magenta metro rail route was proposed on 25.09.2014 originating from existing Botanic Garden metro station (depicted in Plate I : 1 as $\mathrm{M}$ ). Within the range (length and width) of proposed metro route, plant species of different kinds having aesthetic/ ornamental, economic and medicinal values, endemic and threatened species were found planted/conserved partly in areas of Cactus House, lawn, mounds, hedges along the path, arboretum/woodlands (Plate I, 1 \& 2, Plate II, 1 to $6)$ were listed to rescue them from any damage and/or felling and loss forever. Besides, for showcasing the museum specimens and to organise awareness programme for varying range of visitors including student/scholars in the garden, a Porta Cabin (size approx. 6,917 sq.ft.) in the form of an Office-cum-Interpretation Centre was proposed by the Ministry of Environment, Forest and Climate Change (MOEF\&CC) on 11.11.2016 for its construction at allocated site in BGIR with an entry Gate No. 2 (Plate I, 1 as P). The allocated area was previously developed for recreation purpose by laying lawn grass and planting hedge, Cycas, Juniperous, Melaleuca, palms and other species (Plate I, 1 \& 3, Plate II, 7). All existing plant species falling within the range of construction of Porta-Cabin were listed to prevent them from any loss and/or felling (Table 1). Afterwards, as per needful instructions and directions received from competent authorities on 25.09.2014, the rescue work for such marked plants/trees for metro route was started on 11.02.2015 and completed in Mar., 2015. Whereas for Port-Cabin, as per instructions received on 18.04.2017, the transplantation work started on 
19.04.2017 onwards and completed successfully in 4 days on 22.04.2017 (Plate II, 8 to 11 and Plate III, 1 to 9). For construction work of metro route, NOIDA and for Port-Cabin, National Museum for Natural History (NMNH) and Civil Construction Unit (CCU) of MOEF\&CC provided required machineries (JCB and Hydra Crane), manpower and other requisite items. During both the occasion, meteorological data for NOIDA as available on web page at https://www. timeanddate.com (Fig. 1) was collected for proper planning including safety measures and finalising the transplantation work scientifically to enhance the survival rate to the greater extent of the transplanted trees.

Further, depending upon size, type of plant species, conservation status, aesthetic value and spread of roots and root system/network of respective listed plant species, appropriate scientific procedures were followed as described in ANSI (2012), BSI (1989, 2010), Development Bureau (2014), Himelick (1981) and Watson (1996). In accordance to Woodrow (1999), leaves and vegetative growth of the plants as required were removed/trimmed to minimise rate of transpiration (Plate II, 8 and 10, Plate III, 1 to 3). Further, young leaves were properly cared and excavation work started for transplantation manually and mechanically by a JCB (Plate II, 11 and Plate III, 4 to 6). Depending upon spread of roots and its network, root ball of varying sizes (approx. 5 to $6 \mathrm{ft}$ in height and 4 to $8 \mathrm{ft}$ in diameter from top) may weighing approx. 2 to 9 tons were made in accordance as depicted in Fig. 2 and Plate III, 3, 4, 6 and 7. Further, to prevent any damage to the primary, secondary and tertiary roots, rootlets and root hairs in its appropriate position in developed root balls of sandy soil, each of them was wrapped by hessian/jute cloth and secured by jute rope (Plate III, 8 and 9). As the volume of root ball was in tons and required to be transplanted to a distant new location located from $30 \mathrm{~m}$ to $500 \mathrm{~m}$ or more, the root balls of the trees were lifted from the trenching sites and transported slowly in vertical position with intact root ball by a Hydra Crane (Plate IV, 1 to 3). Further, as per the size of each root ball, $2 \mathrm{ft}$ more wide pit than the root ball was developed by a JCB at new location and root balls were gradually placed at suitable depth equivalent to the ground surface and in alignment of row of previously conserved/planted trees (Plate IV, 4 to 7). The pits were then filled with water followed by soil together with further thorough watering (Plate IV, 8 and 9) and sprinkling over the trunk/stem, branches and leaves of trees time to time as required. Then ground surface was firmed and levelled properly. To keep the transplanted tree in vertical position, external support was provided to prevent from unexpected swaying wind and further watered raising soil prop all around (Plate IV, 10 and 11) with thorough sprinkling on erected tree. After taking proper care for a fortnight or so, when leaves not fall at all and/or if fall, appearing of new leaves is evident and at the same time, if the transplanted tree not displaced

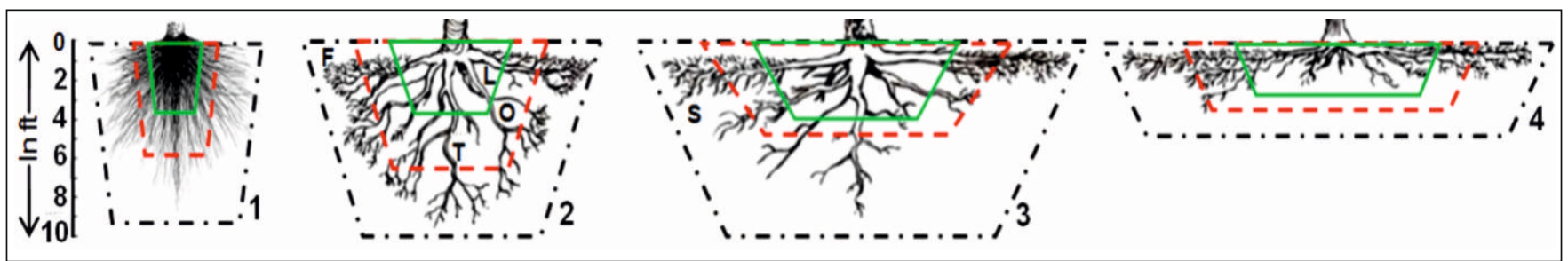

Fig. 2: 1. Fibrous root system of Monocots, 2 . to 4 . Tap root system of Dicots. $\mathrm{F}=$ Fine roots, $\mathrm{L}=\mathrm{Lateral}$ roots, $\mathrm{O}=$ Oblique/heart roots, $\mathrm{S}=$ Sinker roots, $\mathrm{T}$ = Tap root, Black dotted and dash line = Showing spread of whole root system, Red dash line = Showing most part of composite root systems viz. major roots, rootlets and fine roots and Green solid line = Showing most part of major roots and gradually decreasing in number of rootlets and fine roots.

and/or inclined from its vertical position, the external support was taken out.

\section{RESULTS AND DISCUSSION}

New Okhla Industrial Development Authority (NOIDA) is one of the most important industrial, business, medical and recreational hub with scientific and educational institutions including Botanic Garden and Okhla Bird Sanctuary as well as with varying range of residential areas is treated as part of Delhi NCR. In continuation of further development/expansion of NOIDA, they keep on 
Table 1: Plant species existing in alignment of construction sites of piers of magenta metro rail route and Porta-Cabin for Office-cum-Interpretation Centre in Botanic Garden of Indian Republic (BGIR), NOIDA.

\begin{tabular}{|c|c|c|c|c|c|}
\hline S. No. & Name of Plant & Family & Vernacular Name & Status & Number \\
\hline \multicolumn{6}{|c|}{ DBH of Stem $<10 \mathrm{~cm}$} \\
\hline 1. & $\begin{array}{l}\text { Aechmea recurvate (Klotzsch) } \\
\text { L.B. Smith }\end{array}$ & Bromeliaceae & - & Ornamental & 37 \\
\hline 2. & Agave salmiana Otto ex Salm-Dyck & Asparagaceae & Green maguey & LC, Ornamental & 20 \\
\hline 3. & Agave vivipara $\mathrm{L}$. & Asparagaceae & Caribbean agave & LC, Ornamental & 35 \\
\hline 4. & Cassia fistula $\mathrm{L}$. & Fabaceae & $\begin{array}{l}\text { Amaltas, Golden } \\
\text { shower }\end{array}$ & $\begin{array}{l}\text { Endemic, Economic, } \\
\text { Medicinal, Ornamental }\end{array}$ & 10 \\
\hline 5. & Cereus repandus (L.) Mill. & Cactaceae & Hedge cactus & Ornamental & 1 \\
\hline 6. & Duranta erecta $\mathrm{L}$. & Verbenaceae & Golden dewdrop & Ornamental & 220 \\
\hline 7. & Ficus retusa $\mathrm{L}$. & Moraceae & Ficus panda & Ornamental & 8 \\
\hline 8. & Furcraea foetida (L.) Haw. & Asparagaceae & $\begin{array}{l}\text { Green-aloe or } \\
\text { Mauritius-hemp }\end{array}$ & Ornamental & 7 \\
\hline 9. & $\begin{array}{l}\text { Furcrae afoetida (L.) } \\
\text { Haw. Variegated }\end{array}$ & Asparagaceae & $\begin{array}{l}\text { Green-aloe or } \\
\text { Mauritius-hemp }\end{array}$ & Ornamental & 5 \\
\hline 10. & Hamelia patens Jacq. & Rubiaceae & Fire bush & Medicinal, Ornamental & 100 \\
\hline 11. & Hippeastrum reginae (L.) Herb. & Amaryllidaceae & Lily, Amaryllis & Ornamental & 3 \\
\hline 12. & $\begin{array}{l}\text { Hymenocallis littoralis (Jacq.) } \\
\text { Salisb. }\end{array}$ & Amaryllidaceae & Beach spider lily & Ornamental & 32 \\
\hline 13. & Sansevieria trifasciata Prain & Asparagaceae & $\begin{array}{l}\text { Naag paudha, } \\
\text { Snake plant }\end{array}$ & Ornamental & 34 \\
\hline 14. & Sansevieria trifasciata var. babnii & Asparagaceae & $\begin{array}{l}\text { Naag paudha, } \\
\text { Snake plant }\end{array}$ & Ornamental & 17 \\
\hline 15. & Volkameria inermis L. & Lamiaceae & Gory bower & Ornamental & 546 \\
\hline \multicolumn{6}{|c|}{ Sub Total-A } \\
\hline \multicolumn{6}{|c|}{ DBH of Stem $>10 \mathrm{~cm}$} \\
\hline 16. & Bombax ceiba $\mathrm{L}$. & Malvaceae & Semal, Cotton tree & $\begin{array}{l}\text { Endemic, Economic, } \\
\text { Ornamental }\end{array}$ & 1 \\
\hline 17. & Cycas revoluta Thunb. & Cycadaceae & Cycas, Sago palm & $\begin{array}{l}\text { LC, Economic, } \\
\text { Ornamental }\end{array}$ & 7 \\
\hline 18. & Dalbergia latifolia Roxb. & Fabaceae & Indian rosewood & $\begin{array}{l}\text { Endemic, Vulnerable, } \\
\text { Economic }\end{array}$ & 1 \\
\hline 19. & Dalbergia sissoo Roxb. & Fabaceae & $\begin{array}{l}\text { Shisham, North } \\
\text { Indian rosewood }\end{array}$ & $\begin{array}{l}\text { Endemic, LC, } \\
\text { Economic }\end{array}$ & 1 \\
\hline 20. & Hardwickia binata Roxb. & Fabaceae & Anjan & Endemic, Economic & 8 \\
\hline 21. & $\begin{array}{l}\text { Hildegardia populifolia } \\
\text { (Roxb.) Schott. \& Endl. }\end{array}$ & Malvaceae & $\begin{array}{l}\text { Delibuda, Poplar } \\
\text { Sterculia }\end{array}$ & $\begin{array}{l}\text { Endemic, Critically } \\
\text { Endangered }\end{array}$ & 1 \\
\hline 22. & $\begin{array}{l}\text { Lannea coromandelica } \\
\text { (Houtt.) Merr. }\end{array}$ & Anacardiaceae & $\begin{array}{l}\text { Mohin, Indian } \\
\text { ash tree }\end{array}$ & Endemic, Economic & 22 \\
\hline 23. & $\begin{array}{l}\text { Melaleuca bracteata } \\
\text { F. Muell. }\end{array}$ & Myrtaceae & $\begin{array}{l}\text { Nagalinga Black/ } \\
\text { River tea-tree }\end{array}$ & Economic, Ornamental & 2 \\
\hline 24. & $\begin{array}{l}\text { Opuntia littoralis } \\
\text { (Engelm.) Cockerell }\end{array}$ & Cactaceae & Prickly pear cactus & $\begin{array}{l}\text { LC, Economic, } \\
\text { Ornamental }\end{array}$ & 41 \\
\hline
\end{tabular}




\begin{tabular}{|c|c|c|c|c|c|}
\hline 25. & $\begin{array}{l}\text { Pedilanthus bracteatus } \\
\text { (Jacq.) Boiss. }\end{array}$ & Euphorbiaceae & Tall slipper plant & Medicinal, Ornamental & 18 \\
\hline 26. & Pterocarpus marsupium Roxb. & Fabaceae & Vijayasar, Indian kino & $\begin{array}{l}\text { Endemic, Vulnerable, } \\
\text { Economic, Medicinal }\end{array}$ & 4 \\
\hline 27. & $\begin{array}{l}\text { Terminalia arjuna (Roxb.) } \\
\text { Wight \& Arn. }\end{array}$ & Combretaceae & Arjuna, Arjun tree & $\begin{array}{l}\text { Endemic, Economic, } \\
\text { Medicinal }\end{array}$ & 3 \\
\hline 28. & Washingtonia robusta $\mathrm{H}$.Wendl. & Arecaceae & Mexican fan palm & Ornamental & 2 \\
\hline 29. & Wrightia tinctoria (Roxb.) R.Br. & Apocynaceae & $\begin{array}{l}\text { Shwetha Kutaja, } \\
\text { Indrayava }\end{array}$ & Economic, Medicinal & 7 \\
\hline 30. & Yucca capensis L.W. Lenz & Asparagaceae & Cape Region yucca & $\begin{array}{l}\text { Endangered, } \\
\text { Ornamental }\end{array}$ & 42 \\
\hline \multicolumn{5}{|r|}{ Sub Total-B } & 160 \\
\hline \multicolumn{5}{|r|}{ Grand Total-A+B $=C$} & 1,135 \\
\hline 31. & Cycas circinalis $\mathrm{L}$. & Cycadaceae & $\begin{array}{l}\text { Jangli madan, } \\
\text { Gueen sago }\end{array}$ & $\begin{array}{l}\text { Endemic, Endangered, } \\
\text { Medicinal, Ornamental }\end{array}$ & 1 \\
\hline 32. & $\begin{array}{l}\text { Melaleuca bracteata } \\
\text { F. Muell. }\end{array}$ & Myrtaceae & $\begin{array}{l}\text { Nagalinga Black/ } \\
\text { River tea-tree }\end{array}$ & Economic, Ornamental & 1 \\
\hline 33. & Washingtonia robusta $\mathrm{H}$.Wendl. & Arecaceae & Mexican fan palm & Ornamental & 5 \\
\hline \multicolumn{5}{|r|}{ Sub Total-D } & 7 \\
\hline \multicolumn{5}{|r|}{ Grand Total-C+D } & 1,142 \\
\hline
\end{tabular}

developing infrastructures of varying nature. In continuation to provide easy access to the commuters from Indira Gandhi International Airport and/or South West, New Delhi, NOIDA proposed to develop a magenta metro rail route on 25.09.2014 originating from Botanic Garden metro station, NOIDA to Janakpuri West, New Delhi passing through Botanic Garden of Indian Republic (BGIR) depicted in (Plate I, 1). However, within the range (length and width) of proposed metro route, altogether 1,135 individuals of 30 species (having aesthetic/ornamental, economic and medicinal values, endemic and threatened species) depicted in Table 1 were found planted/conserved partly in areas of Cactus House, lawn, mounds, landscape areas, hedges along the path, arboretum/woodlands (Plate I, 1 \& 2 and Plate II, 1 to 6 ). Besides, for showcasing the museum specimens and to organise awareness programme for varying range of visitors (including student/scholars) in the garden, a Porta-Cabin (size approx. 6,917 sq.ft.) in the form of an Office-Cum-Interpretation Centre for National Museum for Natural History (NMNH) was proposed by the Ministry of Environment, Forest and Climate Change (MOEF\&CC) on 11.11.2016 for its construction in BGIR (Plate I, 1, 3 \& 4 and Plate II, 7). The allocated area for Porta-
Cabin was previously developed for recreation purpose by laying lawn grass and planting hedge, Bismarckia nobilis Hildebr. \& H.Wendl., Cycas circinalis L., Juniperus communis L., Melaleuca bracteata F. Muell. and Washingtonia robusta H.Wendl. and listed altogether 7 individuals of 3 genus/species of 3 Family to rescue them from felling. During both the occasion, the environmental condition was not favourable for transplantation. Even then, efforts were made, planned scientifically, applied heavy machineries (instead 'tree spade' as it was not readily available in India, used JCB and Hydra Crane), manpower and logistic as provided, the 'transplantation process' was initiated.

Before execution of transplantation, the plants/trees found within the range (length and width) of alignment of metro route in areas of Cactus House, lawns, mounds, hedges along the path, aesthetically landscaped areas, arboretum/woodlands and construction site of Porta Cabin, altogether 1,142 individual of 31 species belonging to 17 family and 26 genus were found existing/conserved are depicted in Table 1 and Plate I, 1, 2 \& 4, Plate II, 1 to 7. Among the transplanted trees, most species belonged to different categories as endemic (10), least concern 


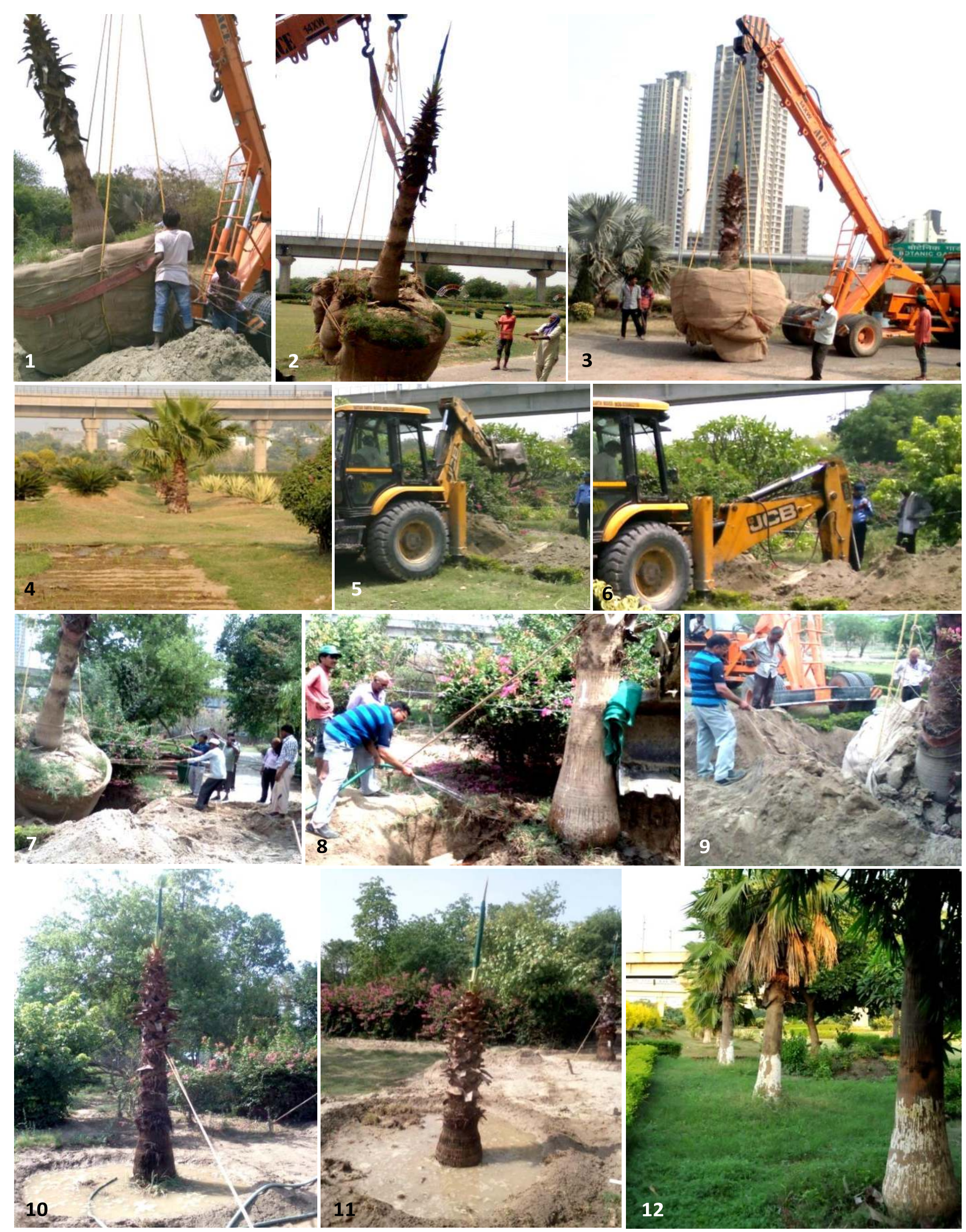

Photo Plate IV: 1 . Root ball after lifting was kept on ground to move further, 2. and 3. Trees on the way to new location, 4.Transplantation site, 5. and 6. Mechanically digging is in progress, 7. Process of placement of root ball in pit/trench in right position, 8. After resting root ball properly in prepared pit, extensively watered, 9. To make transplanted tree stable, pit is gradually filled with soil while watering, 10. and 11. Transplanted tree is supported by rope and watered extensively, 12. Transplanted trees are in alignment. 

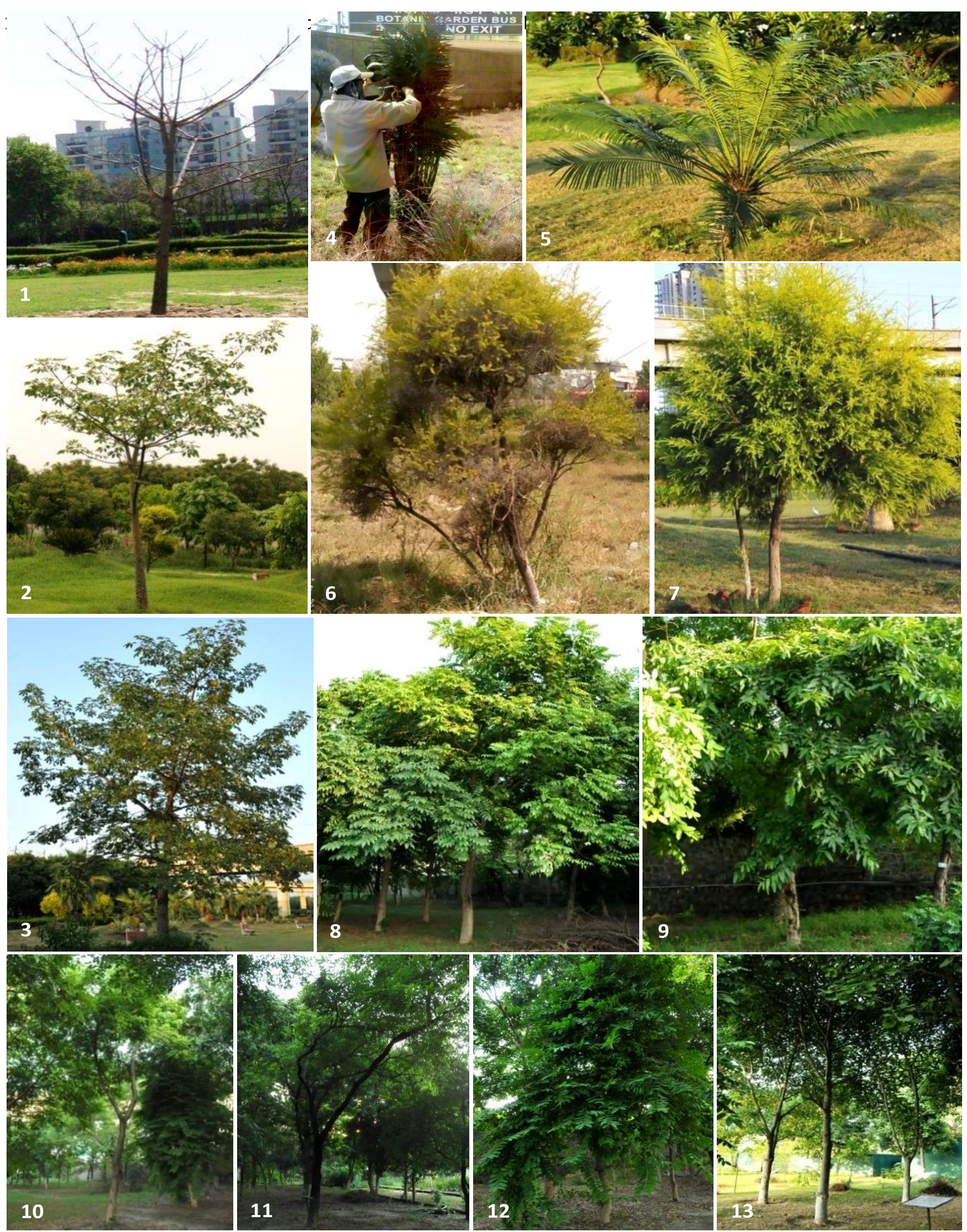

Photo Plate V: 1. to 3. Stages of development of Bombax ceiba L. after transplantation with intact branches and foliage at new location, Before and after transplantation - 4. and 5. Cycas circinalis L., 6. and 7. Melaleuca bracteata F. Muell. and Present condition of transplanted trees - 8. Lannea coromandelica (Houtt.) Merr., 9. Terminalia arjuna (Roxb.) Wight \& Arn., 10. and 11. Pterocarpus marsupium Roxb., 12. Wrightia tinctoria (Roxb.) R.Br. 13. Hildegardia populifolia (Roxb.) Schott. \& Endl. 
(5), vulnerable (2) and 1 each as endangered and critically endangered species whereas 13, 7 and 25 species were having economic, medicinal and ornamental value respectively. As per the norms of Uttar Pradesh Protection of Trees in Rural and Hill Areas Act, 1976 and Uttar Pradesh Protection of Trees (Amendment) Act, 2001, the existence of above plants/trees become one of the major hurdle for execution/augmentation of any construction work. Though, keeping in view of present status of NOIDA as 'township' where BGIR is located and as the garden is being developed by the MOEF\&CC, Government of India, the aforesaid Act of UP Govt. does not apply. However, as per Section $3(\mathrm{v})$, it comes under the purview of the aforesaid Act, fell a tree with its cognate expressions, means cutting, girdling, lopping, pollarding or damaging a tree in any other manner. Hence, considering preventive measures as mentioned in above Act and other Acts like the Indian Forest Act, 1927, Forest (Conservation) Act, 1980, National Forest Policy, 1988 and Forest Act (Amended), 1992 under sustainable development programme as well as considering conservation/aesthetic aspects of such existing herbs, shrubs and trees of such precious species falling under the alignment and construction sites, an alternate feasible mitigation measure i.e. transplantation was followed to transplant them at alternate suitable locations in the garden to avoid felling instead relocation of the projects.

Keeping above facts into consideration and in view of habit and girth size of existing plants in proposed areas, species were further categorised in 2 different categories viz. $<10 \mathrm{~cm}$ dia. girth, the number of individuals were 1,075 of 12 genus and 15 species (belonging to 9 family, 1 endemic, 2 least concern, 1 economic, 2 medicinal and 15 ornamental) and $>10 \mathrm{~cm}$ dia. girth, the number of individuals were 160 of 14 genus and 15 species (belonging to 11 families, 8 endemic, 3 least concern, 2 vulnerable and 1 each as endangered and critically endangered, 12 economic, 6 medicinal and 22 ornamental) in alignment of metro route (Plate I, $1 \& 2$, Plate II, 1 to 11). The recorded meteorological characteristics i.e. temperature (in ${ }^{\circ} \mathrm{C}$ ), percentage humidity and wind velocity (in $\mathrm{kmph}$ ) for NOIDA during the month of transplantation of trees is depicted in
Fig. 1. The atmospheric temperature ranged from 08 to $29{ }^{\circ} \mathrm{C}$ and 13 to $36{ }^{\circ} \mathrm{C}$ during Feb. and Mar., 2015 respectively. Percentage humidity was recorded 24 to 94\% during Feb., 2015 and 31 to 99\% during Mar., 2015 and wind velocity was recorded maximum 19 kmph during Feb., 2015 and $21 \mathrm{kmph}$ during Mar., 2015. The values were not so harsh other than most part of the days of the months was foggy/cloudy and sunny resulted dry weather condition prevailed except light and heavy rainfall recorded on March 01 and 02, 2015. Other than this, these 2 months i.e. February and March are well defined for spring season. During the period, the plant starts preparing for formation of new branches, leaves, floral buds, flowers, fruits/seeds, etc. As a result, the environmental condition of the locality was not conducive for transplantation from the alignment of metro route to a new location and at the same time plants/trees may prepare for their growth/rejuvenate. Hence, as per Woodrow (1999), the execution of such activities for transplantation of huge trees during the period is not advisable to carry out. However, keeping in view of exigency of the infrastructural development, needful scientific steps were taken to maximise survival by removing/trimming vegetative growth/foliage (Plate II, 8 to 10, Plate III, 1 to 3$)$. At the same time to minimise less damage to the roots and root networks by forming root balls as depicted in Fig. 2 to preserve natural posture/positions of roots, rootlets, root hairs in sandy soil (Plate III, 4, 6 \& 7) and secured by providing hessian/jute cloth covering all around (Plate III, 8 \& 9, Plate IV, 1 to 3 \& 7) until the plant was not placed safely/established properly in new locations after transportation in vertical position by a Hydra Crane (Plate IV, 1 to 3 \& 7).

The herbs and shrubby plants were taken out from ground manually after pruning/trimming the foliages of hedge and landscape plants (Plate II, 8 \& 9). Then, root ball was made either alone and/or in groups and transported from existing to new locations using a hand trolley. Among the listed plant species of $<10 \mathrm{~cm}$ girth size, Aechmea recurvate (Klotzsch) L.B. Smith, Agave salmiana Otto ex Salm-Dyck, Agave vivipara L., Cassia fistula L., Cereus repandus (L.) Mill., Hippeastrum reginae (L.) Herb., Hymenocallis littoralis (Jacq.) Salisb., Sansevieria trifasciata Prain and 
Sansevieria trifasciata var. hahnii were transplanted in areas of Cactus House. Duranta erecta L., Ficus retusa L., Hamelia patens Jacq. and Volkameria inermis L. were transplanted in landscape areas for up-gradation and strengthening the existing hedges to enhance the aesthetic views. Such plants were taken care properly for a fortnight to months until and unless the appearance of new leaves/branches or flower buds was witnessed.

Whereas, at construction site of Porta-Cabin, 7 individuals 3 species of $>10 \mathrm{~cm}$ dia. girth size were listed are Cycas circinalis L. (1), Melaleuca bracteata F.Muell. (1) and Washingtonia robusta H.Wendl. (5) belonging to 3 different families (Table 1), among 4 individuals were transplanted $2^{\text {nd }}$ time in last 2 years during Feb./Mar., 2015 and Apr., 2017 (Plate I, 1, 3 \& 4). Broadly, such species are having ornamental values and planted in landscape areas and at the same time the Cycas circinalis L. is considered as endemic, endangered and is having medicinal value whereas the Melaleuca bracteata F.Muell. is having only ornamental value. Overall, as compared to the meteorological characteristic recorded during the month of Feb. and Mar., 2015, the environmental condition was very adverse/harsh and dry during Apr., 2017. The atmospheric temperature ranged from 26 to $42{ }^{\circ} \mathrm{C}$, humidity 16 to $76 \%$ and hot stormy wind velocity was recorded $17 \mathrm{kmph}$ (Fig. 1). Besides this, most part of the days of the month were clear, sunny and without any precipitation. The environmental condition of spot was so adverse and horrifying that one staff each of CCU and NMNH fell ill very next day of augmented transplantation work. After spring season, from April onwards, the summer season begins and when the day remains dry for longer period, it intend plants to face high rate of transpiration. To compensate this, root networks and its components act vigorously and absorb a lot of water from ground. Besides, some trees starts forming new leaves, turn green on maturity to photosynthesize maximum food to supply them in most part of the plants for development of branches, flower buds and bloom vigorously for formation of fruit/seeds. While, others develop flower buds before new leaves appear. As a result, during the month of April and/or summer season, transplantation of plants/trees is avoided (Woodrow, 1999) as during the period, the survival rate of such plants/trees is very less. However, in instant case, the transplantation of 7 trees was carried in exigency with assistance of provided 5 labours and machineries (JCB and Hydra Crane). All listed trees were transplanted successfully by taking additional precautions while trimming leaves, formation of root balls, transportation of trees with root ball in vertical positions, properly placement in newly developed trench, watered thoroughly while filling soil along water (Plate III \& IV, 1 to 9). Further, external supports were provided to face hot swaying winds, watered by raising soil prop and sprinkling water over tree at regular intervals to maximise rate of their survival (Plate IV, 10 \& 11). In this way, the whole work was completed in 4 days from 19.04.2017 to 22.04.2017. On 22.04.2017 (Saturday) most Institutions were celebrating 'Earth Day' by organising series of events whereas, in BGIR all garden's staff as well as staffs of CCU and NMNH marked the day precisely as is truly required and started the transplantation work at 8.30 AM and finished the same by $10.00 \mathrm{PM}$.

After transplantation of all listed plants/trees at new locations, the ground cover was kept moist by sprinkling water at regular intervals over different body parts judiciously for at least a fortnight to one month. On regular monitoring, when no defoliation was observed in transplanted plants/trees and/or in some plants few leaves found fallen and witnessing appearance of new leaves in them disclosed their status as survived one. Other than this, when transplanted plants/trees were not found displaced from its actual vertical position, all provide supports were taken out. In this manner, without using sophisticated 'tree spade' (a specialized machine for transplantation of huge trees) which is rarely available at higher cost, $97.5 \%$ rate of survival of the transplanted plants/trees (Plate V, 1 to 13) was achieved by adopting the manual and mechanical methods with assistance of JCB and Hydra Crane in such an adverse environmental condition, is one of the greatest achievements of whole infrastructural developmental project so far reported. Not only is this, even after 5 to 7 years from date of transplantation, all transplanted trees 
are still standing in their new locations/places in BGIR.

\section{ACKNOWLEDGMENT}

The author is thankful to the Ministry of Environment, Forest and Climate Change and Botanical Survey of India for giving an opportunity to serve as Scientist-In-Charge to look after the Botanic Garden of Indian Republic (BGIR). Besides, thanks are also due to the New Okhla Development Authority (NOIDA), National Museum for Natural History (NMNH) and Civil Construction Unit (CCU), MOEF\&CC, New Delhi for facilitating requisite basic requirements (manpower, machineries and other logistics) as required for transplantation of plants/trees.

\section{REFERENCES}

1. ANSI (2012). ANSI A300 (Part 6)-2012 Trees, Shrub and Other Woody Plant Management Standard Practices (Planting and Transplanting). American National Standards Institute. The Tree Care Industry Association, Inc., Londonderry, NH.36p.

2. Ashok K.V. (2017). Necessity of Ecological Balance for Widespread Biodiversity. Indian Journal of Biology. 4(2): 158-160.

3. BSI (1989). BS 4043:1989 Recommendations for transplanting root-balled trees. British Standards Institute, London. 16p.

4. BSI (2010). BS 3998:2010 Tree workRecommendations. British Standards Institute, London.76p.

5. Das T.M. (1979). Value of a tree. Indian Biologist. 11(1-2): 73-79.
6. Development Bureau (2014). Guidelines on Tree Transplanting. Greening, Landscape and Tree Management Section, Development Bureau, The Government of the Hong Kong Special Administrative Region, Hong Kong. 33p.

7. Himelick E.B. (1981). Tree and Shrub Transplanting Manual. International Society of Arboriculture, Urbana, Ill. 76p.

8. Kumar S. (2021a). Developing saplings in disposable paper glass instead plastic bags. Int. Journal of Biological Innovations. 3(2): 278-285. https://doi.org/10.46505/IJBI. 2021.3205

9. Kumar S. (2021b). Development of a water body for conservation of aquatic biodiversity in Botanic Garden of Indian Republic, NOIDA. Int. Journal of Biological Innovations. 3(2): 342-354. https://doi.org/10.46505/ IJBI.2021.3215.

10. Verma A.K. (2018). Ecological Balance: An Indispensable Need for Human Survival. Journal of Experimental Zoology, India. 21 (1): 407-409.

11. Verma A.K. (2021). Influence of climate change on balanced ecosystem, biodiversity and sustainable development: An overview. International Journal of Biological Innovations. 3(2):331-337. https://doi.org/ 10.46505/IJBI.2021.3213

12. Watson G.W. (1996). Tree Transplanting and Establishment. Arnoldia. 56(4): 11-16.

13. Woodrow G.M. (1999). Gardening in India. Biotech Books, Delhi. 634p. 